\title{
Organizing the Unorganized Lifestyle Retailers in India: An Integrated Framework
}

\author{
H. R. Ganesha ${ }^{1}$, \& P. S. Aithal ${ }^{2}$ \\ ${ }^{1}$ Chief Executive Officer - Consulting Division, Gramss Retail Trading Private Limited, Bengaluru \\ - 560078, India and Post-Doctoral Research Fellow, College of Management \& Commerce, \\ Srinivas University, Mangalore - 575001, India. \\ OrcidID: 0000-0002-5878-8844; E-mail: hrganesha@yahoo.co.in \\ ${ }^{2}$ Vice Chancellor, Srinivas University, Mangalore - 575001, India. \\ OrcidID: 0000-0002-4691-8736; E-mail: psaithal@gmail.com
}

Subject Area: Business Management.

Type of the Paper: Empirical Study.

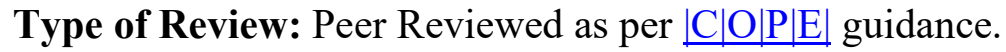

Indexed In: OpenAIRE.

DOI: http://doi.org/10.5281/zenodo.

Google Scholar Citation: IJAEML.

\section{How to Cite this Paper:}

Ganesha, H. R., \& Aithal, P. S. (2020). Organizing the Unorganized Lifestyle Retailers in India: An Integrated Framework. International Journal of Applied Engineering and Management Letters (IJAEML), 4(1), 257-278. DOI: http://doi.org/10.5281/zenodo.

International Journal of Applied Engineering and Management Letters (IJAEML)

A Refereed International Journal of Srinivas University, India.

(C) With Authors.

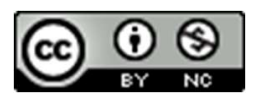

This work is licensed under a Creative Commons Attribution-Non-Commercial 4.0 International License subject to proper citation to the publication source of the work.

Disclaimer: The scholarly papers as reviewed and published by the Srinivas Publications (S.P.), India are the views and opinions of their respective authors and are not the views or opinions of the S.P. The S.P. disclaims of any harm or loss caused due to the published content to any party. 


\title{
Organizing the Unorganized Lifestyle Retailers in India: An Integrated Framework
}

\author{
H. R. Ganesha ${ }^{1}, \&$ P. S. Aithal ${ }^{2}$ \\ ${ }^{1}$ Chief Executive Officer - Consulting Division, Gramss Retail Trading Private Limited, Bengaluru \\ - 560078, India and Post-Doctoral Research Fellow, College of Management \& Commerce, \\ Srinivas University, Mangalore - 575001, India. \\ OrcidID: 0000-0002-5878-8844; E-mail: hrganesha@yahoo.co.in \\ ${ }^{2}$ Vice Chancellor, Srinivas University, Mangalore - 575001, India. \\ OrcidID: 0000-0002-4691-8736; E-mail: psaithal@gmail.com
}

\begin{abstract}
India is one of the largest countries with consumers belonging to the widest range of Religions, Regions, Languages, Sub-Cultures, Ethnicities, and Economic backgrounds which makes it difficult for just a few organized lifestyle retailers to service divergent needs of such consumers. This makes it furthermore beneficial for unorganized lifestyle retailers spread across India in humongous numbers which are predominantly owned and operated by the store owner and their family members to take such divergent consumer needs to their advantage as far as their survival is concerned. Unless they attempt to adopt certain modifications and changes to their existing retailing model and store image this benefit will no longer be available to them in the long run. Organized lifestyle retailing in India is steadily growing its penetration into Tier-2 and Tier- 3 cities and this is putting unorganized lifestyle retailers in these cities in quandary. In this study, we have analysed twelve months actual data across, (a) unit economics; (b) returns on investment; (c) 94 business deployment factors; (d) 192 critical effective factors; and, (e) qualitative factors of few select organized and unorganized lifestyle retailers in India thereby drawing inferences / insights to design and propose an integrated framework which is, (a) simple to understand; (b) easy to execute; and most importantly;(c) demanding minimal additional capital investment and would possibly help unorganized lifestyle retailers in India to get organized.
\end{abstract}

Keywords: Indian Retail, Lifestyle Stores, Brick-and-Mortar Stores, Organized Retail, Unorganized Retail, Store Image, Mom and Pop Stores, Aatmanirbhar Bharat, Self-Reliant India.

\section{INTRODUCTION :}

1.1.Unorganized Lifestyle Retailing in India: For the purpose of limiting the focus of this research study, we define unorganized lifestyle retailers in India as, brick-and-mortar retail stores managed and operated by store owners and their family members themselves, offering lifestyle products such as Apparel, Footwear and Accessories, to consumers located in and around the store's catchment area and most importantly the sales pitch of sales personnel in the store is push technique driven owing to the concealed merchandise display methodology adopted. Each individual wants to have a unique identity which could be based on his / her, a) background such as nationality, ethnicity, culture, subculture, social class, affiliation, environment, etc; b) experiences and c) choices. Lifestyle retailers in fact attempt to evoke emotional connections between consumers and their need to have a unique identity and most importantly lifestyle retailers are increasingly becoming one of the key components of consumer's self-expression [1]. Lifestyle retail market size in India is expected to reach 130 billion USD by the year 2023 which is a 77 percent growth when compared to the year 2013 [2]. Based on India's 2011 census, United Nation's (UN) Department of Statistics and Programme Implementation estimates Indian population to reach close to 1.38 billion by the year 2020 [3]. It is estimated that more than 300 Global lifestyle brands have plans to open their stores in India this year [4]. In addition to this humongous population, exponential growth in number of working women, double income families, middle-class consumer segment, increasing disposable income, rapid adoption of fashion, urbanization, overall size of Indian retail industry, emergence of modern retailing formats and most importantly enormous increase 
in internet penetration / usage, simply cautions existing and upcoming unorganized lifestyle retailers to revisit their retailing strategies and models. Notwithstanding this paradigmatic change, as far as India is concerned researches need to note that unorganized lifestyle retailers have not given up majority of their market share to organized lifestyle retailers which could possibly be attributed to Indian consumer's buying and patronage behaviour with respect to lifestyle retail stores in India.

1.2. Organized Lifestyle Retailing in India: Owing to the sheer market size and potential, India is able to attract many Global lifestyle brands who have successfully become lifestyle retailers too. Few Global retailers have attempted to offer their product assortment as being an SIS at select large MBO stores, few have offered their product assortment through having EBOs, few have shown their presence only in online stores and few have licensed their brands to third parties or entered into a Joint Venture to offer their products in Indian retail market. To name a few Decathlon, Lifestyle, Max, Levi's, Zara, United Colors of Benetton, Marks \& Spenser, H\&M, Mother Care, Carter's, Puma, Nike, Adidas, Reebok, Armani Exchange, Diesel, Gas, Gap, The Children's Place, Quiksilver, Superdry, Kappa, Bossini, Calvin Klein, Hanes, Tommy Hilfiger, Ed Hardy, Izod, Nautica, Arrow, U.S. Polo Assn, Jack \& Jones, Vero Moda, Tumi, Lee, Hero, Maverick, Wrangler, Fila and Jockey. Unless these Global lifestyle retailers explore sourcing their products predominantly from India, competitive pricing remains one of the key challenges as far as their sustainable success in Indian market is concerned. India also is a home for vast number of lifestyle brands originated from India. One can possibly list more than 5000 lifestyle brands in India [5], of which one could possibly list only a few which can be tagged as well-known / familiar / reputed Indian lifestyle brands cum retailers such as, Biba, Manyavar, Soch, Gini \& Jony, Blackberrys, Louis Phillipe, Peter England, Provogue, Monte Carlo, Mufti, W for Women, Oxemberg, Indian Terrain, Global Desi, Parx, S Kumar's, Vimal, Mini Klub, Aurelia, Sparx, Campus, Go Colors, Enamour, HiDesign, Lino Perros, Idee, Spykar, Killer Jeans, Flying Machine, Da Milano, Park Avenue, Ethnix, ColorPlus, Lux Cozy, Wild Craft, 612 League, WLS, John Players, Fastrack, 109 F, Proline, Image, Jealous 21, Liberty, Paragon and few more. Few of these are successful in becoming organized lifestyle retailers catering to specific product categories and specific consumer groups. Few companies have been able to establish themselves as pure Indian organized lifestyle retailers who cater to multi-category, multi-brand, multi-location and multi-consumer groups and it is evident that one can list all of them as there are only few National level retailers such as a) Westside, b) Shoppers Stop, c) Central, d) FBB, e) First Cry, f) Toons, g) Wildcraft, h) Indian Terrain, i) Pantaloons, j) Brand Factory and few Regional level retailers such as, a) Kapsons, b) Ritu Wears Big Life, c) Stanmax, d) Bindals, e) Sohum Shoppe, f) City Life, g) Chunmun, h) Jade Blue, i) Neeru's, j) Mebaz, k) V-Mart, 1) The Chennai Silks, m) Saravana Stores, n) M\&M, o) Sirs \& Hers, p) Juelle, q) G3 Fashions, r) Pothy’s, s) RMKV, t) Naidu Hall, u) Chandana Brothers, v) Nalli, and w) Kalyan Silks. It is evident that only few names have appeared in the organized lifestyle retailers list which is possibly indicating that in spite of humongous population and the retail market size in India, majority of Indian lifestyle brands and retailers have failed to establish themselves as organized lifestyle retailers and we would attribute majority of this failure to their existing retailing model in addition to strong loyalty of consumers to unorganized lifestyles retailers in India.

1.3. Consumer's Retailing Format Choice: As per McKinsey Global Institute study, by year 2030, urban agglomerations in India could possibly lead to increase in the middle-class consumer segment by 3 times compared to year 2010 which was at 22 million; people living in urban cities is expected to increase to 590 million and most important cities with more than one million population will increase to 68 [6]. India is one of the most sought-after countries for retailing opportunities globally, mainly because of i) higher population consisting of relatively younger population, and ii) higher penetration of internet users. India is witnessing rapid expansion of national and international brands/companies into Tier 2 and Tier 3 cities such as Housing, Automobiles, IT, Banking and most importantly Retail Stores owing to; i) exponential growth in urbanization of Tier 2 and Tier 3 cities post-economic liberation, ii) government's interest and plans for improving basic infrastructure at Tier 2 and Tier 3 cities, vi) relatively cheaper real estate and most importantly vi) steadily increasing disposable income level of consumers in Tier 2 and Tier 3 cities. These developments and numbers are clear indicators of upcoming changes that are expected in the way consumers will behave while choosing retail stores to purchase their lifestyle needs in addition to cautioning unorganized lifestyle retailers to get organized to ensure they sustain their existing consumer base and the business. Consumer's store and retailer choice angle to store location is the one which puts many lifestyle retailers whether organized or not in quandary while considering the store location which is one of the key determinants of overall store image and retailing costs. It is inevitable for organized lifestyle brands and retailers to have their presence in as many 
different locations and distribution channel partner's stores as possible to have a competitive advantage over competitors and especially unorganized local favourites. Nevertheless, if unorganized lifestyle retailers fail to adopt basic aspects of organized retailing model and store image, it will possibly lead them to lose market share to organized lifestyle retailers.

\section{LITERATURE REVIEW :}

2.1. Store image had been one of the key elements of the retailing mix studied in the past. Lindquist was the first to list the key components of store image construct in the year 1974. Based on past studies Lindquist listed eight components of store image construct viz., i) merchandise, ii) clientele, iii) physical facilities, iv) convenience, v) promotion, vi) store atmosphere, vii) institutional factors and viii) post-transactional satisfaction [7]. Later researchers have confirmed that the basic attributes of store image construct as listed by Lindquist in 1974 remain unchanged [8] and were able to add few more attributes to store image construct such as ix) customer service, $x$ ) personal selling, and xi) sales incentive programs [9].Few studies argue that these factors together influence the overall store image in consumers minds only when the consumers have experienced these factors through actual shopping [10]. There have been many studies confirming a positive correlation between store layout and consumer loyalty [11 to 13]. Consumers perception of store image varies with store layout and consumers shopping at different store formats having different store layouts create their own perception of store image in their mind [14]. Extending these studies recommend bricks-and-mortar retailers to align their store layout design keeping their target consumers in mind rather adopting standard layout designs [15]. Retailers need to consider various location specific factors while planning for expansion such as a) attractiveness of the market, b) number of stores to be opened per market, c) store locations and d) ideal store size for each of these stores. In this study, they clearly indicate that every store needs to have size optimal for the location and market it is present rather a standard size being adopted across all the stores of a particular retailing format. In all these studies nowhere, researchers recommend retailers to adopt different price level of merchandise for different locations of stores [16]. A retailer having a unique store image and using this unique store image as one of the key promotional and marketing/advertising propositions can possibly yield competitive advantage and it is important to note that copying a store image which is complex in its nature is a difficult task for competitors [17]. One of the most important determinants of retailer success is store image [18]. Retailers need to clearly understand various environmental factors relating to store image influencing their target consumers. It is very important to design strategies relating to store an image in a specific location in relation to retailers target consumers in that particular environment [19]. Majority of retailers design strategies relating to specific locations based on the consumer behaviour pattern and knowledge available in the general market in the specific location which is also based on the general consumer population [20]. These strategies lead retailers to align most of the store image attributes to the general consumer population and hence they might possibly fail to maintain their principal brand/store image standard across various locations or geographies. Retailer's store success and consumer loyalty is majorly influenced by store image along with store positioning and product-price differentiation in relation to market. Retailers could possibly use such store image attributes to promote and advertise their positioning in the consumers mind [21 - 22].Store location is not just about the physical space which has been occupied by a store, it is actually a catchment area of a store which witnesses heavy commercial and economic activities [23]. Store size and location are the most important components of retailing as far as enhancing consumer experience is concerned. Few reputed retail brands like Zara have increased their store sizes exponentially along with changing the type of locations in the past, few retail brands such as Debenhams and Mother Care have downsized their existing store sizes to incorporate improved operating efficiencies, few retail brands such as Tesco entered city centre locations with smaller sized stores, few continually kept rationalizing their store sizes and few still believe that larger the store size higher the consumer walk-ins [24]. One of the biggest challenges faced by brick-andmortar retailers is the higher cost involved in expanding store sizes even though it helps them in enhancing the overall consumer shopping experience. Retailers are finding it extremely difficult to find relevant spaces in the right locations owing to higher rentals and lesser spaces available in key retail locations [25], which proposes retailers to consider mall kiosks as one possible retailing format which can be cost effective as far as expensive rentals are concerned. It is true that store location plays an influential role in consumer store choice decisions, at the same time store location being a long-term capital lock-in decision plays an important role for retailer's overall strategic planning. Any location which has inherent properties of attracting consumers is the best location for any retailer and having a store in such locations brings both strategic and competitive advantages 
to the retailer, whereas, it will take longer time and huge store losses for any retailer to come out of a bad store location. Good store location could also be analysed by; a) the amount of relevant consumer traffic flow be it, pedestrian traffic or vehicular traffic; b) parking facilities; c) store composition; d) specific site; e) terms of occupancy, f) accessibility, g) travelling time, h) location convenience, i) other complimentary stores present in the catchment [26]. Through our previous empirical and experimental research studies, we have concluded that; (i) if retailer considers building premium store image in consumers, competitors, and investors mind as the key indicator of judging best location for a store, mall stores are the ideal ones, and if the retailer is interested in overall retail performance with consistent growth and sustainable profits then a rational mix of each of these locations is the ideal solution[27]; (ii) there is no significant variance in contribution of different price bands to overall bills / invoices and revenue being generated by stores across Tier 1, Tier 2 and Tier 3 cities for a retailer who runs all these stores under a single store brand name and results have shown that stores in Tier 2 and Tier 3 cities generate lesser revenue compared to Tier 1 city stores and this must not be mistaken as consumers in cities other than Tier1 cities face affordability issue [28]; and (iii) the fourth and important elements of Marketing Mix 'place' need be aligned based on the product / category grouping in relation to target consumer group and catchment area [29].

2.2. Consumer preference or choice of brand and the success of a brand depends upon the brand's personality. It is important for the marketer to constantly work on strategies to convert the existing brand image into equity [30]. Few researchers have investigated the correlation among the competition of brands, formation of consumers' attitude and intention to choose a particular brand or alternatives being offered to the consumers at a given point of time and the place of the offering. Findings of these studies confirm that consumers' evaluations, understandings, and knowledge about a particular brand of their choice are not just the key influencer of creating intentions of buying a product belonging to a brand, it is also consumers' perspectives and perceptions toward another alternative or brand available in the offering [31]. There are few brands which have gained strong brand equity owing to consumers having special, favourable association with such brands in their memories and these brands were able to create higher perceived quality, awareness about the brand name and ultimately leading huge loyal consumers over a period of time [32-34]. Consumers tend to correlate their personality with the brand personality they are willing to associate with, wherein they attribute this to their demographic characteristics, physical characteristics, personal traits and, cognitive abilities consequently leading them to buy a brand's product to implicitly or explicitly express / showcase their personal image or identity [35 - 36]. Abundant literature is available on Brand personality, image, equity, experience, association, advertisement, endorsements, and loyalty as a result of contributions from many researchers across domains.

2.3.Unorganized retailing had been one of the key research studies in the Policy Making and Economics domain since late 60 's. Traditional retailing formats were perceived to be inefficient and weak in various aspects and hence successful modernization policies to be implemented in countries having majority of retailing in the unorganized form [37]. Many countries have implemented policies favouring unorganized and informal sectors such as; (i) in the year 1979 Singapore Government launched 'Hawker centres upgrading programme', (ii) Taiwan launched upgrading programme for 'Old wet markets' in 1979; and, (iii) Russia and South Korea launched development programme for traditional sector in 1990 and in spite of many recommendations India is yet to launch such programmes [38]. Singapore's 'retail sector development plan' initiative which was launched in the year 1992 even though driven by an exclusive organization 'Retail Promotion Center' which attempted to upgrade unorganized, informal and small-scale retailers was unsuccessful due to limited access and control over convincing the retailers [39]. Organizing the unorganized retailing required additional capital investment which is not easily available on credit to small-scale retailers, many countries have assisted unorganized retailers through capital support to withstand challenges posed by organized and modern retailers, the capital assistance aspect is one of the most important aspects to convince and encourage unorganized retailers to get organized which in turn shall boost the overall economy of a country [40]. Unorganized / small retailers are better in comparison to organized retailers such as,(a) they know the 'likes and dislikes' of their consumers, (b) customization while product showcasing, promotions and even information regarding new arrivals are higher, (c) credit facility to their loyal consumers, (d) easier systems and processes with respect to product returns and exchanges, (e) easy to shop for daily needs, (f) convenience of store location which is almost a neighbourhood store, and $(\mathrm{g})$ store owners involvement with local communities and clubs, however, unorganized retailers must attempt to work on few aspects of their retailing model to gain an additional competitive advantage over organized retailers such as, (i) efficient supply chain and inventory management, (ii) matching discounts and offers with organized retailer's discounts and offers, 
and (iii) open merchandise display techniques [41 - 47]. In spite of many studies indicating that the Indian retail market is all set to reach a trillion US Dollars, the fear of organizing retailers taking the market share away from unorganized retailers in India is not justified [48]. Few studies have also expressed their concerns on predatory pricing being used as one of the tactics by the organized retailers to penetrate into new markets which are predominantly serviced by unorganized retailers [49]. Approximately 80 percent of unorganized / small-scale retailing in India is run by family owned business houses in other words it represents 9.6 million stores, and this is one of the largest numbers of small-scale stores present in a country [50]. Many researchers have also focussed on studying the influence of unorganized retailing with respect to the overall economy of a nation and argued that, a) overall economy of a country could be analysed based on the revenue and employment the retailing sector is generating, b) it is inevitable to continuously focus on improving key aspects of retail operations, systems, supply chain and processes which could possibly lead to better economy of a country, c) constant innovations in the business models have a positive impact on the overall performance of retailing company [51 - 53].

2.4. Need for this research aroused when we found that majority of empirical, theoretical, and descriptive literature available on the unorganized retailing in India focusses on analysing pros and cons of organized and unorganized retailing. We were not able to find frameworks which could guide unorganized lifestyle retailers in India to organize themselves to withstand increasing competition and market penetration from organized lifestyle retailers with which we could answer our research questions such as; (a) should we believe that the existing retailing model of lifestyle retailers in India is an appropriate strategy?; (b) should we believe that the existing retailing model is delivering optimal revenue and profit for the unorganized lifestyle retailers?; (c) should we believe that the existing retailing strategy is aligned with retailer's target consumers and consumer's changing attitude towards unorganized retailing?; (d) is it a misconception among unorganized lifestyle retailers in India that consumers are attracted to stores / retail formats located very close to their residence and these consumers tend to continue shopping in these mom and pop stores just because the store location is convenient? and; (e) are these unorganized lifestyle retailers aware of the impact on their sustainability and even existence owing to constantly growing market penetration of organized lifestyle retailers in India? Thus, we decided to select few National level, Regional level, Local level organized Indian lifestyle retailers in addition to few unorganized lifestyle retailers across the country, understand their existing retailing model, empirically evaluate their actual sales and consumer data in relation to retailer's key business goal, thereby drawing insights to recommend unorganized lifestyle retailers in India an integrated framework to gain longterm strategic and competitive advantage in addition to establishing themselves as organized lifestyle retailers image across their existing and potential employees, investors, competitors, and consumers mind. Most importantly unorganized lifestyle retailing being one of the major contributors to Indian GDP it is inevitable for these retailers to get organized thereby supporting the country's new vision of Aatmanirbhar Bharat / SelfReliant India.

\section{OBJECTIVES :}

Key objectives of this research were to, i) understand lifestyle retailing market in India; ii) understand evolution and performance of lifestyle retailing in India; iii) understand the unit economics of organized and unorganized lifestyle retailers in India; iv) compare organized and unorganized lifestyle retailing in India; v) analyse recommendations from previous research studies; vi) determine key concepts which could possibly help unorganized lifestyle retailers to get organized; vii) design and propose an integrated framework, and vii) recommend a systematic approach for executing the integrated framework.

\section{METHODOLOGY:}

4.1. Secondary Research: Intense and in-depth analysis of data available in the public domain was carried to collect data relating to various aspects of organized and unorganized lifestyle retailers in India through company websites, company annual financial reports, Government data base, trade, and business journals. Research works relating to Indian lifestyle brands was surveyed extensively to collect insights, recommendations, and frameworks.

4.2. Quantitative Primary Research: In the first stage, few organized and unorganized lifestyle retailers in India were selected who can represent, a) different product categories such as fashion, functional, life-stage specific, product specific, gender specific, and need specific products; b) offering single-product category and multiple-product categories; c) serving different consumer target groups at low, mid-low, mid, mid-high, high, 
and premium price positioning; d)having single and multiple stores; e) offering single brand and multiple brands; f) having presence across Tier-1, Tier-2 and Tier-3 cities; g) having stores across high street, malls, institutions and neighbourhoods, and h) new and established retail store image. In the second stage, twelve months actual data was collected from these select organized and unorganized lifestyle retailers to quantitatively map their existing retailing model and draw inferences.

4.3. Qualitative Primary Research: Series of open-ended direct interviews were conducted with employees selected through convenience sampling representing different departments/functions from Brands, Distributors and Retailers viz., Human Resource Development, Training, Strategy, Category, Communication, Customer Relationship, Warehousing, Finance, Information Technology, Sales, Distribution, Stores Operation along with Store Sales Personnel across select organized and unorganized lifestyle retailers in India to understand their perspective and attitude towards their existing retailing model and its implications on the overall performance and store image.

\section{KEY FINDINGS AND INSIGHTS :}

5.1. Qualitative: Prior to the empirical study, we were able to derive qualitative insights through mystery shopping and conduct open-ended direct interviews with employees representing all the departments and functions of lifestyle retailers chosen for the study. Key insights from the qualitative survey indicate that, these lifestyle retailers strongly had numerous beliefs and assumptions as detailed below separately for organized and unorganized retailers.

5.1.1. Unorganized Lifestyle Retailers: Key perceptions which were unanimous among the unorganized retailers were, a) for the products we offer in our stores it is less likely that our consumers purchase from elsewhere; b) unlike organized retailers we do not communicate anything to our consumers which is a computer driven, rather we call each consumer on our own to communicate any specific product and promotion information relevant for them while talking to them in general on matters unrelated to retailing; c) we buy only what sells and we know what is required by our consumers for which we do not require a computer to guide us on managing stocks in the store; d) majority of our product's original price (MRP) itself is so low as compared to organized retailers which is already known to our consumers and hence offering additional discounts is not a mandatory requirement; e) as we know the complete history, background, socio-economic status of every consumer and their family we showcase and recommend products based on these criterion; f) our consumers belief on us as owners of the shop overrides any deficiencies if at all found in the products and service we offer to them; g) we are more bothered about consistent and constant cash flow generated by the store rather only profits as we are aware of the fact that the store being operational since generations has already given us enough profits; $h$ ) sales personnel in our stores are committed and loyal to us and very rarely they disassociate from us; i) notwithstanding we pay less to our sales personnel compared to organized retailer, we make sure that we do solve their personal problems (both monetary and non-monetary) often; $\mathrm{j}$ ) we need not to train our sales personnel as they are well versed with our product assortment; $\mathrm{k}$ ) unlike organized retailers we do not use mass social media to connect with our consumers, WhatsApp is enough and is much more stronger tool to get connected with our consumers regularly; 1) we do renovate our store once in a year even though it is at a smaller scale; $\mathrm{m}$ ) we offer more trendy products aligned to latest trends inspired by the Indian Cinema as our supply chain is of small-scale and we manage to test many new products at lower inventory risks; $n$ ) our product assortment also has few National and Global brands in it; $\mathrm{o}$ ) we do sell premium and high priced products, and p) decision making of any magnitude does not take longer time as we are appraised of all the activities related to our stores.

5.1.2. Organized Lifestyle Retailing: Key perceptions which were unanimous among the organized retailers were, a) more than online retailers, unorganized retailers are the biggest threat for us; $b$ ) unorganized retailers sell products which are sold at cheap prices with no guarantee on the product quality and durability; c) consumers need to spend some time in planning their shopping at organized retail stores which is not the case when it comes to shopping at unorganized retail shops owing their stores being located very close to consumers residence; d) we are struggling to witness success at Tier- 2 and Tire- 3 cities as consumers in these cities are still loyal to unorganized retailers; e) we spend a lot of time and money in communicating to consumers using all the latest software tools and solutions; f) our sales personnel are well groomed and trained and they are paid much higher than unorganized retailers; g) attrition rate of our sales personnel is significantly high; $h$ ) we follow open merchandise display techniques which enable consumers to choose their best choice unlike unorganized retailer who showcase only few products / models / brands to consumers; i) we have robust 
systems and standard operating procedures across all the processes of retailing; $j$ ) we offer best National and Global brands in addition to Private labels to consumers; k) we give the same shopping experience to consumers across all our stores irrespective of the city; 1) revenue generated by our stores is significantly higher than unorganized stores; $m$ ) consumers spend is significantly higher in our stores; $n$ ) share of loyal and repeat consumers is significantly less in our stores; o) every transaction in organized retailing is trackable and traceable by government authorities thereby we contribute to Government's revenue by paying all kinds of taxes; p) we follow standard weights and measures guidelines on all our packaging and products tagging thereby maintaining transparency of product information with our consumers; $q$ ) we follow standard hierarchy systems for any decision making thereby ensuring unbiased decisions being taken; and, r) consumers believe in organized retailing as there is transparency across all the aspects.

5.2. Empirical: Interestingly, when we evaluated actual data related to product assortment, sales, consumers, supply chain partners, inventory level, inventory turns, product sell through and velocity, capital investment requirement, returns on investment, decision making process, communication techniques, discount methodologies, organization structure, and sales pitch techniques we have found many insights of which some are contrary and some are matching with what was believed by both the organized and unorganized lifestyle retailers as detailed below.

5.2.1. Unit Economics: Majority of lifestyle retailers in the study were not well versed with the concept of 'unit economics'. Thus, we attempted to understand the unit economics of stores across organized and unorganized lifestyle retailers in the study which could possibly enable us to understand the economical pros and cons of both the retailing models empirically rather than just looking at the qualitative pros and cons of these models. Table 1 shows the end to end flow of parameters for a lifestyle store. It was also observed that most of these parameters were never tracked by lifestyle retailers. Each of these parameters have been compared line by line between organized and unorganized retailing models in addition to capturing the percentage variance in an unorganized lifestyle retailing model with respect to organized retailing model. Based on this comparison we have noted that organized retailers were superior in comparison to unorganized retailers in parameters pertaining to, a) intake margin level by 31.80 percentage points which is almost double; b) average product pricing higher by 81.82 percent; c) annualized inventory turns by 96.05 percent; d) quantity sold by 30.04 percent; e) sales per day per square foot by 80.29 percent; f) revenue by 2.11 times and, g) gross earnings by 4.66 times. Whereas, an unorganized retailers were superior in comparison to organized retailers in parameters pertaining to, a) optimal utilization of trading area by 16.91 percent owing to the common area loading being 2.35 times lesser; b) product display density higher by 33.33 percent; c) number of product options being stocked in the store higher by 33.33 percent; d) annualized discounts lower by 2.32 times; e) store rental expenses by 3.74 times; f) store employee costs by 4.29 times; g) store overheads by 5.56 times; h) warehousing and logistics expenses by 33.73 times; i) store level EBITDA earning by 50.54 percent, and most importantly; j) net earnings for every unit of product being sold to consumers being higher by 62.16 percent. These findings demonstrate that the organized lifestyle retailers even though generate higher revenue and gross margins in comparison to unorganized retailers, they are significantly poor in generating higher store level profits in spite of 2.11 times higher revenue being generated at 4.66 times higher gross margin earnings, they generate 0.49 times lesser store level profits. Retailing expenditures of organized lifestyle retailers are significantly higher owing to their store location choice, store design, store organization structure and the overall ambiance they create for the consumers to have superior shopping experience as compared to unorganized lifestyle retailers. Results also indicate that if organized retailers attempt to reduce (predatory pricing) their original product price positioning to compete with unorganized lifestyle retailers then it is possible that organized retailers might even start losing the existing store level profits. This particular element has directed us to take an empirical look at the returns on investment (ROI) parameters for both lifestyle retailing models in the study to evaluate if organized retailing is superior in terms of ROI at least. 
Table 1: Store level unit economics and the variance among key parameters of organized and unorganized lifestyle retailers in India.

\begin{tabular}{|c|c|c|c|c|c|}
\hline \multirow{2}{*}{ Particulars } & \multicolumn{2}{|c|}{ Organized Lifestyle Retailer } & \multicolumn{2}{|c|}{$\begin{array}{c}\text { Unorganized Life style } \\
\text { Retailer }\end{array}$} & \multirow{2}{*}{ Variance } \\
\hline & Value & $\%$ of Revenue & Value & $\%$ of Revenue & \\
\hline Trading Area $(S F T)$ & 2000 & $\mathrm{Na}$ & 2000 & $\mathrm{Na}$ & $0.00 \%$ \\
\hline Common Area Loading (\%) & $33.60 \%$ & $\mathrm{Na}$ & $14.28 \%$ & $\mathrm{Na}$ & $-135.29 \%$ \\
\hline Carpet Area $(S F T)$ & 2672 & $\mathrm{Na}$ & 2286 & $\mathrm{Na}$ & $-16.91 \%$ \\
\hline Minimum Display Quantity (Pieces) & 11180 & $\mathrm{Na}$ & 16770 & $\mathrm{Na}$ & $33.33 \%$ \\
\hline Minimum Display Options Available in the Store & 621 & $\mathrm{Na}$ & 932 & $\mathrm{Na}$ & $33.33 \%$ \\
\hline Average MRP (INR) & 986 & $\mathrm{Na}$ & 542 & $\mathrm{Na}$ & $-81.82 \%$ \\
\hline Intake Margin on MRP & $61.80 \%$ & $\mathrm{Na}$ & $30.00 \%$ & $\mathrm{Na}$ & $-106.00 \%$ \\
\hline Average Product Base Cost (INR) & 377 & $\mathrm{Na}$ & 380 & $\mathrm{Na}$ & $0.78 \%$ \\
\hline Return Sales Quantity (Pieces per Month) & 28 & $\mathrm{Na}$ & 11 & $\mathrm{Na}$ & $-161.40 \%$ \\
\hline Net Sales Quantity (Pieces per Month) & 2749 & $\mathrm{Na}$ & 2114 & $\mathrm{Na}$ & $-30.04 \%$ \\
\hline Sales MRP Value (INR Lacs per Month) & 27.10 & $127.50 \%$ & 11.46 & $113.66 \%$ & $-136.45 \%$ \\
\hline Annual Discount (\%) & $17.65 \%$ & $\mathrm{Na}$ & $7.62 \%$ & $\mathrm{Na}$ & $-131.63 \%$ \\
\hline Discount Value (INR Lacs per Month) & 4.78 & $22.50 \%$ & 0.87 & $8.66 \%$ & $-447.67 \%$ \\
\hline Gross Sales Value (INR Lacs per Month) & 22.32 & $105.00 \%$ & 10.59 & $105.00 \%$ & $-110.77 \%$ \\
\hline Average Selling Price (INR per Piece) & 812 & $\mathrm{Na}$ & 501 & $\mathrm{Na}$ & $-62.08 \%$ \\
\hline $\mathrm{SPF}(I N R)$ & 27.84 & $\mathrm{Na}$ & 15.44 & $\mathrm{Na}$ & $-80.29 \%$ \\
\hline Secondary Tax (\%) & $5 \%$ & $0.24 \%$ & $5 \%$ & $0.50 \%$ & $0.00 \%$ \\
\hline Secondary Tax Value (INR Lacs per Month) & 1.06 & $5.00 \%$ & 0.50 & $5.00 \%$ & $-110.77 \%$ \\
\hline Store Rent Value (INR Lacs per Month) & 4.01 & $18.86 \%$ & 1.10 & $10.88 \%$ & $-265.33 \%$ \\
\hline CAM per SFT (INR per Month) & 12.59 & $\mathrm{Na}$ & 2.85 & $\mathrm{Na}$ & $-341.75 \%$ \\
\hline Store CAM Value (INR Lacs per Month) & 0.34 & $1.58 \%$ & 0.07 & $0.65 \%$ & $-416.44 \%$ \\
\hline SFT Covered by One Sales Personnel & 300 & $\mathrm{Na}$ & 600 & $\mathrm{Na}$ & $50.00 \%$ \\
\hline Sales Personnel Head Count & 9 & $\mathrm{Na}$ & 4 & $\mathrm{Na}$ & $-133.81 \%$ \\
\hline Store Managers Head Count & 2 & $\mathrm{Na}$ & 1 & $\mathrm{Na}$ & $-100.00 \%$ \\
\hline Store House Keeping Personnel Head Count & 1 & $\mathrm{Na}$ & 1 & $\mathrm{Na}$ & $0.00 \%$ \\
\hline Store Security Personnel Head Count & 1 & $\mathrm{Na}$ & 0 & $\mathrm{Na}$ & $0.00 \%$ \\
\hline Total Employee Cost (INR Lacs per Month) & 2.02 & $9.48 \%$ & 0.47 & $4.66 \%$ & $-329.17 \%$ \\
\hline Store Overheads per SFT (INR per Month) & 54.68 & $\mathrm{Na}$ & 11.50 & $\mathrm{Na}$ & $-375.48 \%$ \\
\hline Store Overheads Cost (INR Lacs per Month) & 1.46 & $6.87 \%$ & 0.26 & $2.61 \%$ & $-455.86 \%$ \\
\hline Bank and Finance Charges (INR Lacs per Month) & 0.33 & $1.58 \%$ & 0.00 & $0.00 \%$ & $0.00 \%$ \\
\hline Brand Promotional Cost (INR Lacs per Month) & 1.56 & $7.35 \%$ & 0.05 & $0.53 \%$ & $-2850.83 \%$ \\
\hline Warehousing Expenses (INR Lacs per Month) & 0.85 & $4.00 \%$ & 0.03 & $0.25 \%$ & $-3272.38 \%$ \\
\hline Logistics Expenses (INR Lacs per Month) & 0.85 & $4.00 \%$ & 0.03 & $0.25 \%$ & $-3272.38 \%$ \\
\hline Shrinkage Provision (INR Lacs per Month) & 0.279 & $1.31 \%$ & 0.026 & $0.26 \%$ & $-953.87 \%$ \\
\hline Total Retailing Cost (INR Lacs per Month) & 11.70 & $55.04 \%$ & 2.02 & $20.08 \%$ & $-477.77 \%$ \\
\hline EBITDA Value (INR Lacs per Month) & 0.27 & $1.26 \%$ & 0.54 & $5.36 \%$ & $50.54 \%$ \\
\hline EBITDA (\%) & $1.26 \%$ & $\mathrm{Na}$ & $5.36 \%$ & $\mathrm{Na}$ & $76.53 \%$ \\
\hline
\end{tabular}

5.2.2. Returns on Investment: It was observed that the unorganized lifestyle retailers performance evaluation attitude was more skewed towards evaluating their performance on the basis of ROI in comparison with organized retailers. Most of the organized retailer's key result areas (KRA) and key performance indicators 
(KPI) were skewed towards absolute revenue and percentage gross margin generated by the store whereas, only few organized retailers were tracking store level EBITDA earnings. Table 2 captures key parameters which are detrimental in evaluating the ROI for organized and unorganized lifestyle retailers in addition to indicating the percentage variance in unorganized retailing model over organized retailing model. Unorganized lifestyle retailing model has shown a significant 2.64 times higher ROI compared to organized retailing model thereby making it easier for unorganized retailers to recover the capital invested in launching a store significantly earlier than organized retailers. Most of the expenditures of organized lifestyle retailers in the capital expenditure are significantly higher owing to their store location choice, store design, store organization structure and the overall ambiance they are required to create for the consumers to have superior shopping experience as compared to unorganized lifestyle retailers.

Table 2: Returns on investment (ROI) and the variance among organized and unorganized lifestyle retailers in India.

\begin{tabular}{|l|r|r|r|}
\hline Particulars & $\begin{array}{r}\text { Organized } \\
\text { Lifestyle Retailer }\end{array}$ & $\begin{array}{r}\text { Unorganized } \\
\text { Lifes tyle Retailer }\end{array}$ & 2000 \\
Variance \\
\hline Trading Area (SFT) & $33.60 \%$ & 2000 & $0.00 \%$ \\
\hline Common Area Loading (\%) & 2672 & $14.28 \%$ & $-135.29 \%$ \\
\hline Carpet Area (SFT) & 42.11 & 2286 & $-16.91 \%$ \\
\hline First Time Investment on Inventory (INR Lacs) & 2500.00 & 63.66 & $33.85 \%$ \\
\hline One-Time Interiors and Store Set Up Cost per SFT & 66.80 & 950.00 & $-163.16 \%$ \\
\hline One-Time Interiors and Store Set Up Cost (INR Lacs) & 3.50 & 21.71 & $-207.65 \%$ \\
\hline Realty Partner's Refundable Security Deposit (INR Lacs) & 112.41 & 0.75 & $-366.67 \%$ \\
\hline Total Capital Requirement per Store (INR Lacs) & 140.37 & 86.12 & $-30.52 \%$ \\
\hline Total Operating Expenses per Anum(INR Lacs) & 3.21 & 24.30 & $-477.77 \%$ \\
\hline Total EBITDA Earning per Anum (INR Lacs) & $\mathbf{2 . 9 5 \%}$ & 6.49 & $50.54 \%$ \\
\hline Returns on Investment at Store Level (\%) & 33.95 & $\mathbf{7 . 6 0 \%}$ & $\mathbf{6 1 . 2 3 \%}$ \\
\hline Number of Years Required to Recover Capital Invested & & 13.16 & $-157.93 \%$ \\
\hline
\end{tabular}

5.3. Relative Comparison: Among all the business model analysis techniques available such as a) ' $\mathrm{SWOT}$ Strength, Weakness, Opportunity, and Threat'; b) 'CPM - Competitive Profile Matrix'; c) 'IFE - Internal Factor Evaluation'; d) 'EFE - External Factor Evaluation'; e) 'BCG - Boston Consulting Group matrix'; f) 'Porter's Five Forces Model'; g) 'PESTLE - Political, Economic, Social, Technological, Legal, and Environmental Analysis'; and h) 'ABCD - Advantages, Benefits, Constraints, and Disadvantages analysis model' we chose the 'ABCD' analysis technique as the same covers vast factors determining the success of a business model [54 - 55]. 'ABCD' analysis technique by its nature is subjective and exploratory. To make sure we make it objective and empirical we have assigned values ' 0 and 1' for each of the 192 'critical effective elements' of the 'ABCD' analysis model wherein ' 0 ' represents one being 'inferior' in comparison to other and ' 1 ' represents one being 'superior' to another in this relative comparative study. Assigning these values enabled us to convert subjective results to objective outcomes. Before we come up with inferences and insights it was necessary for us to carry out a relative comparison analysis in as much detailed manner as possible. This detailed comparative analysis demanded us to cover vast number of constructs, elements and sub-elements of the organized and unorganized lifestyle retailing models keeping sustainable retailing model while designing the integrated framework for unorganized lifestyle retailers in India to get organized, and 192 'critical effective elements' in addition to 94 'key business deployment factors' outlined in the 'ABCD' analysis model were able to cover majority of the aspects an empirical relative comparative analysis of business models require. 
Table 3: Comparison between organized and unorganized lifestyle retailers using $\mathrm{ABCD}$ analysis:

\begin{tabular}{|c|c|c|c|c|c|}
\hline \multicolumn{6}{|c|}{ Advantages (A) } \\
\hline Areas of Focus & Business Deployment Factors & Critical Effective Ele ments & $\begin{array}{l}\text { Organized Lifestyle } \\
\text { Retailer (O) }\end{array}$ & $\begin{array}{c}\text { Unorganized Lifestyle } \\
\text { Retailer } \\
\text { (U) }\end{array}$ & Superior \\
\hline \multirow{10}{*}{ Organizational } & \multirow{2}{*}{ Investment \& Return } & Asset Value & 1 & 0 & $\mathrm{O}$ \\
\hline & & Profit Orientation & 0 & 1 & $\mathrm{U}$ \\
\hline & \multirow{2}{*}{ Diversity \& Specialization } & Multi-functional & 1 & 0 & $\mathrm{O}$ \\
\hline & & Anticipating cash flow & 0 & 1 & $\mathrm{U}$ \\
\hline & \multirow{2}{*}{ Availability \& Depletion } & Supply \& Demand & 0 & 1 & $\mathrm{U}$ \\
\hline & & Pricing & 0 & 1 & $\mathrm{U}$ \\
\hline & \multirow{2}{*}{ Viability \& Stagnation } & Readiness to change & 1 & 0 & $\mathrm{O}$ \\
\hline & & Ability to Absorb market trends & 1 & 1 & $O \& U$ \\
\hline & \multirow{2}{*}{ Organizational value } & Revenue generation & 1 & 0 & $\mathrm{O}$ \\
\hline & & Worth of the business & 1 & 1 & $O \& U$ \\
\hline \multirow{8}{*}{ Operational } & \multirow{2}{*}{ Resource Utilization } & Incessant workflow & 0 & 1 & $\mathrm{U}$ \\
\hline & & Balancing demand & 1 & 1 & $O \& U$ \\
\hline & \multirow{2}{*}{ Cost effectiveness } & Price fixation & 1 & 1 & $O \& U$ \\
\hline & & Product design & 1 & 1 & $O \& U$ \\
\hline & \multirow{2}{*}{ Core Competency } & Product quality & 1 & 1 & $O \& U$ \\
\hline & & Service effectiveness & 1 & 1 & $O \& U$ \\
\hline & \multirow{2}{*}{ Time } & Gross output & 1 & 0 & $\mathrm{O}$ \\
\hline & & Optimum utilization & 0 & 1 & $\mathrm{U}$ \\
\hline \multirow{6}{*}{ Technological } & \multirow{2}{*}{ Level of technology } & Extent of sophistication & 1 & 0 & $\mathrm{O}$ \\
\hline & & Preparedness & 1 & 0 & $\mathrm{O}$ \\
\hline & \multirow{2}{*}{$\begin{array}{l}\text { Degree of dependency on } \\
\text { Technology }\end{array}$} & Indispensability & 0 & 1 & $\mathrm{U}$ \\
\hline & & Master-servant relationship & 0 & 1 & $\mathrm{U}$ \\
\hline & \multirow{2}{*}{ Institutional readiness to use upgraded technology } & Existing conditions & 1 & 0 & $\mathrm{O}$ \\
\hline & & Product specialty & 1 & 0 & $\mathrm{O}$ \\
\hline \multirow{8}{*}{ Employees \& Employers } & \multirow{2}{*}{ Availability } & Man power supply & 0 & 1 & $\mathrm{U}$ \\
\hline & & Level of skill & 1 & 0 & $\mathrm{O}$ \\
\hline & \multirow{2}{*}{ Satisfaction level } & Compensation rewards & 1 & 0 & $\mathrm{O}$ \\
\hline & & Recognition & 1 & 1 & $O \& U$ \\
\hline & \multirow{2}{*}{$\begin{array}{l}\text { Maintenance cost } \\
\text { (Cost-Satisfaction Trade-off.) }\end{array}$} & Human relations & 1 & 1 & $O \& U$ \\
\hline & & Control Mechanisms & 1 & 1 & $O \& U$ \\
\hline & Sustainability & Motivation & 1 & 1 & $O \& U$ \\
\hline & Sustamability & Commitment & 0 & 1 & $\mathrm{U}$ \\
\hline & IThiouitous A vailability & Market absorption & 1 & 0 & $\mathrm{O}$ \\
\hline & Ubıquitous Avallabllity & Business networking & 1 & 1 & $O \& U$ \\
\hline & Price & Affordability & 1 & 1 & $O \& U$ \\
\hline & Price & Competition & 1 & 1 & $O \& U$ \\
\hline Sas & Dumolitito & Enhanced life & 1 & 0 & $\mathrm{O}$ \\
\hline Consumers & Durability & Superior Innovation & 1 & 0 & $\mathrm{O}$ \\
\hline & User Friendly & Customer nature & 1 & 1 & $O \& U$ \\
\hline & User Friendly & Manner of use & 1 & 0 & $\mathrm{O}$ \\
\hline & D. 1010 & Acceptance & 0 & 1 & $\mathrm{U}$ \\
\hline & Percesved Value & Importance & 1 & 0 & $\mathrm{O}$ \\
\hline & & Hazards minimized & 1 & 0 & $\mathrm{O}$ \\
\hline & Eco friendly & Clean environment & 1 & 0 & $\mathrm{O}$ \\
\hline & Employment Generation & Opportunity creation & 1 & 0 & $\mathrm{O}$ \\
\hline Sociol/Fnviranmental & Employment Generation & Increased earnings & 1 & 0 & $\mathrm{O}$ \\
\hline Social / Environmental & Stake holders Satisfaction & Supplementing necessities & 0 & 1 & $\mathrm{U}$ \\
\hline & Stake holders Satisfaction & Full filling public interest & 1 & 1 & $O \& U$ \\
\hline & Contribution to Economy & Wealth creation & 1 & 1 & $O \& U$ \\
\hline & Contribution to Economy & Maintaining Standards & 1 & 0 & $\mathrm{O}$ \\
\hline
\end{tabular}

5.3.1. Advantages: Out of 50 critical effective elements outlined in the comparison of advantages across six key areas of focus such as, i) organizational, ii) operational; iii) technological; iv) employees and employers; v) consumers and, vi) social and environmental, organized retailing model is superior in majority of the critical effective elements as compared to unorganized retailing model by 31.03 percent. Unorganized retailing model loses to organized mostly in the technological, consumers and socio-environmental areas of evaluation. 
Table 4: Comparison between organized and unorganized lifestyle retailers using ABCD analysis: Benefits.

\section{Benefits (B)}

\begin{tabular}{|c|c|c|c|c|c|}
\hline Areas of Focus & $\begin{array}{l}\text { Business Deployment } \\
\text { Factors }\end{array}$ & Critical Effective Elements & $\begin{array}{l}\text { Organized Lifestyle } \\
\text { Retailer (O) }\end{array}$ & $\begin{array}{c}\text { Unorganize d Lifes style } \\
\text { Retailer } \\
\text { (U) }\end{array}$ & Superior \\
\hline \multirow{8}{*}{ Organizational } & \multirow{2}{*}{ Financial stability } & Productivity & 1 & 0 & $\mathrm{O}$ \\
\hline & & Income generated & 1 & 0 & $\mathrm{O}$ \\
\hline & \multirow{2}{*}{ Product maneuverability } & Adherence to quality & 1 & 1 & $O \& U$ \\
\hline & & Utility value & 1 & 1 & $\mathrm{O} \& \mathrm{U}$ \\
\hline & \multirow{2}{*}{ Resource Assessment } & Anticipating inventory & 0 & 1 & $\mathrm{U}$ \\
\hline & & Complacence to budget & 0 & 1 & $\mathrm{U}$ \\
\hline & \multirow{2}{*}{ Marketability } & Market sensitivity & 0 & 1 & $\mathrm{U}$ \\
\hline & & Product feasibility & 0 & 1 & $\mathrm{U}$ \\
\hline \multirow{8}{*}{ Operational } & \multirow{2}{*}{ Process efficiency } & Simple to work & 0 & 1 & $\mathrm{U}$ \\
\hline & & Low wastage & 0 & 1 & $\mathrm{U}$ \\
\hline & \multirow{2}{*}{ Product Pricing } & Determine profit & 0 & 1 & $\mathrm{U}$ \\
\hline & & Long term goals & 1 & 0 & $\mathrm{O}$ \\
\hline & \multirow{2}{*}{ Product superiority } & Quality & 1 & 1 & $\mathrm{O} \& \mathrm{U}$ \\
\hline & & Features & 1 & 1 & $\mathrm{O} \& \mathrm{U}$ \\
\hline & \multirow{2}{*}{ Speed } & Quick result & 0 & 1 & $\mathrm{U}$ \\
\hline & & Ensuring quality & 1 & 1 & $\mathrm{O} \& \mathrm{U}$ \\
\hline \multirow{6}{*}{ Technological } & \multirow{2}{*}{ Availability } & Chief \& affordable & 1 & 0 & $\mathrm{O}$ \\
\hline & & Suited to the requirement & 1 & 1 & $\mathrm{O} \& \mathrm{U}$ \\
\hline & \multirow{2}{*}{ Technical superiority } & Meeting Standard & 1 & 1 & $\mathrm{O} \& \mathrm{U}$ \\
\hline & & Up to date & 1 & 1 & $\mathrm{O} \& \mathrm{U}$ \\
\hline & \multirow{2}{*}{ Ability to handle } & Easier \& safer & 1 & 0 & $\mathrm{O}$ \\
\hline & & Skill \& familiarity & 1 & 0 & $\mathrm{O}$ \\
\hline \multirow{8}{*}{ Employees \& Employers } & \multirow{2}{*}{ Utilization } & Equitable load & 1 & 1 & $\mathrm{O} \& \mathrm{U}$ \\
\hline & & Better performance & 0 & 1 & $\mathrm{U}$ \\
\hline & \multirow{2}{*}{ Output orientation } & Break-even & 0 & 1 & $\mathrm{U}$ \\
\hline & & Target focus & 0 & 1 & $\mathrm{U}$ \\
\hline & \multirow{2}{*}{ Organizational Structure } & Hierarchies & 0 & 1 & $\mathrm{U}$ \\
\hline & & Command \& Communication & 0 & 1 & $\mathrm{U}$ \\
\hline & \multirow{2}{*}{ Mutuality } & Interaction & 0 & 1 & $\mathrm{U}$ \\
\hline & & Dependability & 0 & 1 & $\mathrm{U}$ \\
\hline \multirow{8}{*}{ Cons umers } & \multirow{2}{*}{ Freedom of choice } & Competing features & 1 & 1 & $\mathrm{O} \& \mathrm{U}$ \\
\hline & & Suited to desire & 1 & 0 & $\mathrm{O}$ \\
\hline & \multirow{2}{*}{ Fitting to the Budget } & Paying capacity & 1 & 1 & $\mathrm{O} \& \mathrm{U}$ \\
\hline & & Attraction \& liking & 1 & 0 & $\mathrm{O}$ \\
\hline & \multirow{2}{*}{ Lasting to use } & Economy & 0 & 0 & \\
\hline & & Preference Factor & 1 & 1 & $\mathrm{O} \& \mathrm{U}$ \\
\hline & Matching expectations & Consider valuable & 0 & 1 & $\mathrm{U}$ \\
\hline & & Good to use & 0 & 1 & $\mathrm{U}$ \\
\hline & Harmony with nature & Green energy & 0 & 1 & $\mathrm{U}$ \\
\hline & H & Green habitat & 0 & 1 & $\mathrm{U}$ \\
\hline & Expanded workforce & More jobs & 1 & 0 & $\mathrm{O}$ \\
\hline Social/Enyironmental & & Increasing skills & 1 & 0 & $\mathrm{O}$ \\
\hline  & Fulfilled interest & Better returns & 0 & 1 & $\mathrm{U}$ \\
\hline & 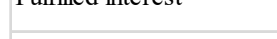 & Meaningful involvement & 1 & 1 & $\mathrm{O} \& \mathrm{U}$ \\
\hline & Improved economy & High per capita & 1 & 1 & $\mathrm{O} \& \mathrm{U}$ \\
\hline & & Better living conditions & 1 & 1 & O \& U \\
\hline
\end{tabular}

5.3.2. Benefits: Out of 46 critical effective elements outlined in the advantages comparison across six key areas of focus such as i) organizational, ii) operational; iii) technological; iv) employees and employers; v) consumers and, vi) social and environmental, unorganized retailing model is superior in majority of the effective elements as compared to organized retailing model by 28.57 percent. Organized retailing model loses to unorganized mostly in the organizational, operational and employees / employers areas of evaluation.

5.3.3 Constraints: Out of 48 critical effective elements outlined in the advantages comparison across six key areas of focus such as i) organizational, ii) operational; iii) technological; iv) employees and employers; v) consumers and, vi) social and environmental, unorganized retailing model is superior in majority of the effective elements as compared to organized retailing model by 236.36 percent. Organized retailing model loses to unorganized in almost all the areas of evaluation. 
Table 5: Comparison between organized and unorganized lifestyle retailers using $\mathrm{ABCD}$ analysis:

Constraints.

\section{Constraints (C)}



5.3.4 Disadvantages: Out of 48 critical effective elements outlined in the advantages comparison across six key areas of focus such as i) organizational, ii) operational; iii) technological; iv) employees and employers; v) consumers and, vi) social and environmental, unorganized retailing model is superior in majority of the effective elements as compared to organized retailing model by 105.88 percent. Organized retailing model loses to unorganized in almost all the areas of evaluation. 
Table 6: Comparison between organized and unorganized lifestyle retailers using ABCD analysis:

\begin{tabular}{|c|c|c|c|c|c|}
\hline \multicolumn{6}{|c|}{ Disadvantages (D) } \\
\hline Areas of Focus & Business Deployment Factors & Critical Effective Elements & $\begin{array}{l}\text { Organized Lifes tyle } \\
\text { Retailer (O) }\end{array}$ & $\begin{array}{c}\text { Unorganize d Lifestyle } \\
\text { Retailer } \\
\text { (U) }\end{array}$ & Superior \\
\hline \multirow{8}{*}{ Organizational } & \multirow{2}{*}{ Organisation structure } & Flat structure / tall structure & 0 & 1 & $\mathrm{U}$ \\
\hline & & Reporting authorities & 0 & 1 & $\mathrm{U}$ \\
\hline & \multirow{2}{*}{ Organisational culture } & Values and belief & 1 & 0 & $\mathrm{O}$ \\
\hline & & Strong Vs Weak culture & 0 & 1 & $\mathrm{U}$ \\
\hline & \multirow{2}{*}{ Organisational type } & Partnership / Corporation & 0 & 1 & $\mathrm{U}$ \\
\hline & & Industrial structure & 0 & 1 & $\mathrm{U}$ \\
\hline & \multirow{2}{*}{ Organisational strategy } & Long / Short term orientation & 1 & 0 & $\mathrm{O}$ \\
\hline & & Implementation & 1 & 0 & $\mathrm{O}$ \\
\hline \multirow{8}{*}{ Operational } & \multirow{2}{*}{ Production Planning } & Forecasting & 0 & 1 & $\mathrm{U}$ \\
\hline & & Prediction & 0 & 1 & $\mathrm{U}$ \\
\hline & \multirow{2}{*}{ Coordination of all functions } & From supply to sale & 1 & 0 & $\mathrm{O}$ \\
\hline & & Tangible to Intangible & 1 & 0 & $\mathrm{O}$ \\
\hline & \multirow{2}{*}{ Operations control } & Quality standards & 1 & 0 & $\mathrm{O}$ \\
\hline & & Budget control & 0 & 1 & $\mathrm{U}$ \\
\hline & \multirow{2}{*}{ Production strategies } & Long / Short term & 1 & 1 & $O \& U$ \\
\hline & & Implementation / Evaluation & 0 & 1 & $\mathrm{U}$ \\
\hline \multirow{8}{*}{ Technological } & \multirow{2}{*}{ Disconnectedness } & People from people & 1 & 1 & $O \& U$ \\
\hline & & People from final product & 1 & 1 & $O \& U$ \\
\hline & \multirow{2}{*}{ Distractions } & Online gaming & 0 & 1 & U \\
\hline & & Online shopping & 0 & 1 & $\mathrm{U}$ \\
\hline & \multirow{2}{*}{ Cyber crimes } & Frauds & 0 & 1 & $\mathrm{U}$ \\
\hline & & Consumer information & 0 & 1 & $\mathrm{U}$ \\
\hline & \multirow{2}{*}{ Expensive } & Purchasing lost & 0 & 1 & $\mathrm{U}$ \\
\hline & & Ongoing maintenance expenses & 0 & 1 & $\mathrm{U}$ \\
\hline \multirow{8}{*}{ Employees \& Employers } & \multirow{2}{*}{ Labour unions } & Membership & 0 & 1 & $\mathrm{U}$ \\
\hline & & Bargaining power & 0 & 1 & $\mathrm{U}$ \\
\hline & \multirow{2}{*}{ Employee disengagement } & $\%$ of Employees engaged & 0 & 1 & $\mathrm{U}$ \\
\hline & & $\%$ of Employees empowered & 0 & 1 & $\mathrm{U}$ \\
\hline & \multirow{2}{*}{ Absence of knowledge workers } & Innovative & 1 & 0 & $\mathrm{O}$ \\
\hline & & Creative & 1 & 0 & $\mathrm{O}$ \\
\hline & \multirow{2}{*}{ Lack of learning organization } & Continuous improvement & 1 & 0 & $\mathrm{O}$ \\
\hline & & Sharing of knowledge & 1 & 0 & $\mathrm{O}$ \\
\hline & Customer preferences and & Ever-changing & 0 & 1 & $\mathrm{U}$ \\
\hline & perception & Unaware & 0 & 1 & $\mathrm{U}$ \\
\hline & Wrong STP (Segmentation & Misidentifying target market & 0 & 1 & $\mathrm{U}$ \\
\hline Consumers & Targeting and Positioning) & Wrong positioning \& segmenting & 0 & 1 & $\mathrm{U}$ \\
\hline Consumers & Customer loyalty & Differentiation & 1 & 0 & $\mathrm{O}$ \\
\hline & Education and promotion & Good Brand management & 1 & 0 & $\mathrm{O}$ \\
\hline & Uogistics & Warehousing & 0 & 1 & $\mathrm{U}$ \\
\hline & Logistics & Inventory handling & 0 & 1 & $\mathrm{U}$ \\
\hline & Environmental Hazards & Pollution & 0 & 1 & $\mathrm{U}$ \\
\hline & Environmental Hazards & Acid air & 0 & 1 & $\mathrm{U}$ \\
\hline & Depletion of natural resources & Wastage & 0 & 1 & $\mathrm{U}$ \\
\hline Social/Fnvironmental & Depletion of natural resources & Recycle \& Reuse & 0 & 1 & $\mathrm{U}$ \\
\hline Social/Environmental & Instability Economic / & Erratic growth & 0 & 1 & $\mathrm{U}$ \\
\hline & Political Environment & Unstable political affairs & 0 & 1 & $\mathrm{U}$ \\
\hline & & Imparity in Pay, crime & 1 & 1 & $O \& U$ \\
\hline & Social problems and Ethical values & Only profit motive & 1 & 0 & $\mathrm{O}$ \\
\hline
\end{tabular}

In summary, the subjective comparison between organized and unorganized lifestyle retailing model indicates that organized retailers owing to their organization structure, decision making processes in addition to the models basic requirement to adhere to Government norms, standard systems, processes and investments their retailing model demands faces serious issues in comparison with unorganized retailing model especially in the 'constraints' and 'disadvantages' components of 'ABCD' relative comparison analysis technique. At an overall level unorganized retailing model is 49.45 percent superior in relative comparison with organized lifestyle retailing model in India.

\section{PROPOSED INTEGRATED FRAMEWORK :}

We have used the basic principles of "4P's" Marketing Mix proposition designed by McCarthy 60 years ago to design the proposed integrated framework which is expected to enable unorganized lifestyle retailers in India to get organized [56]. We would like to define key concepts of the proposed integrated framework before 
we head to explain the effective execution of the framework.

All the instructions to Store Employees to be communicated by only one nominated member of the Owner Family in addition to Empowering Store Employees with Systematic and Rigorous Control Systems.

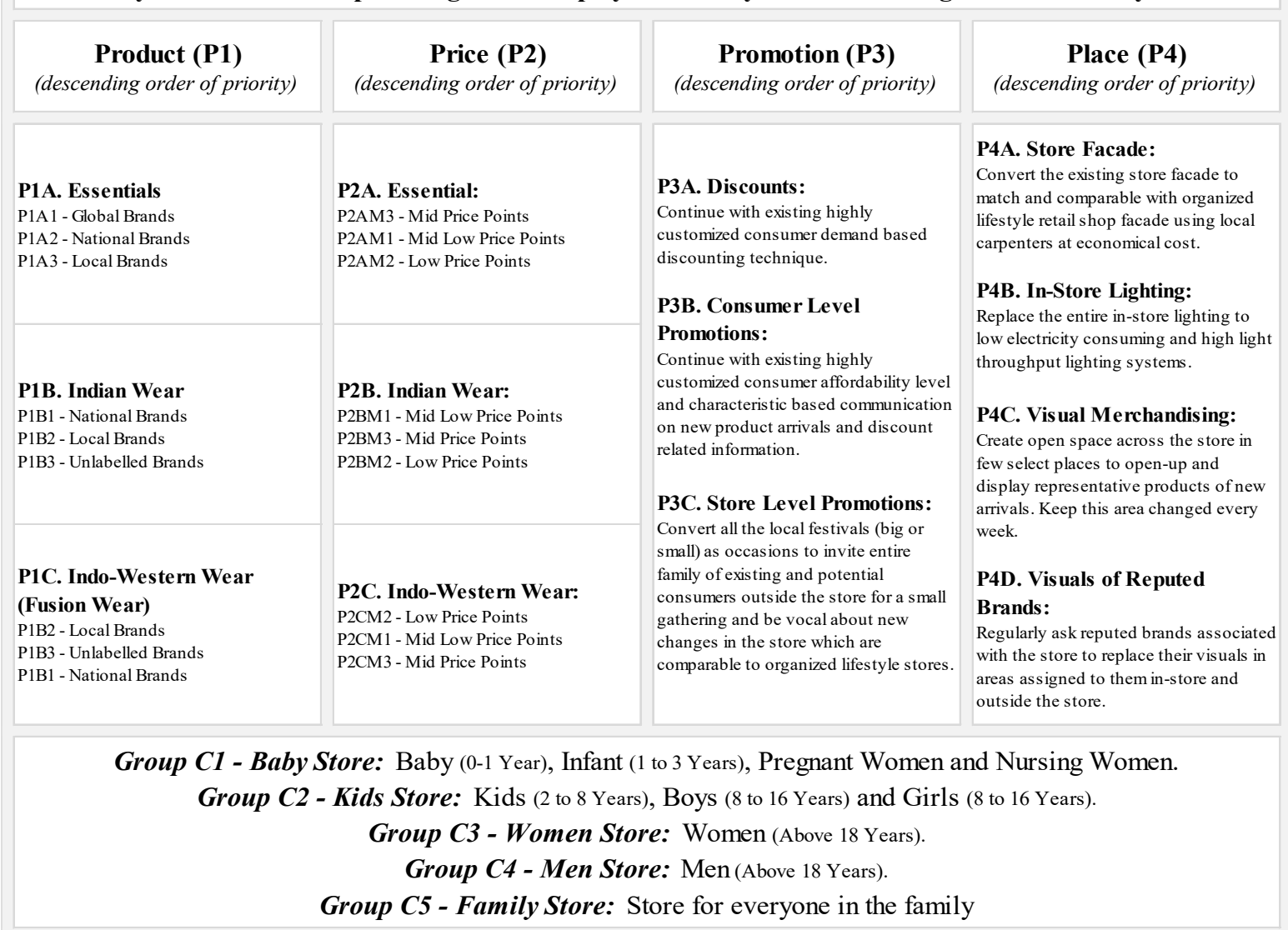

Framework 1: Recommended integrated framework to enable unorganized lifestyle retailers to get organized.

6.1. Product (P1): Considering both supply and demand side attributes of unorganized lifestyle retailing model, we have classified products into different groups in the proposed framework. This grouping is based on numerous empirical and experimental research we have previously carried out and are relevant to Indian retailing context along with being helpful in getting all the store owners and store employees to focus on products / categories which are already proven to be capable of driving consumer repeat store visit frequency thereby enhancing consumers intention to get associated with their store on a long-term basis in addition to findings from this study [57 - 61]. Essential (P1A): All the SKUs of the store which are required by the consumers for frequent usage and are 'need to-have' category of consumers wardrobe or in simple terms a daily need. For example, Inner Wear or Daily Wear. Indian Wear (P1B): All the SKUs of the store which represent Indian clothing or Ethnic fashion which is created based on the existing or forecasted market / Indian fashion trend and are required by the consumers for the lesser frequency of usage as compared to essential products and are 'want to-have' category of consumers wardrobe. For example, Kurta, Social media inspired Handbag, Movie inspired Sunglass, etc. Indo-Western or Fusion Wear (P1C): All the SKUs of the store which are the combination of Indian / Ethnic fashion and Western fashion which is created based on the existing or forecasted market / Indian fashion trend and are required by the consumers for lesser frequency of usage as compared to Indian wear products and are 'demand to-have' category of consumers wardrobe. For example, Fusion Top for Women, Shirts with Ethic Motifs for Men, etc. We have also allocated brand preference for each of these product groups such as, a) Global Brands, b) National Brands, c) Local Brands, and d) Unlabelled Brands.

6.2. Price (P2): Irrespective of the overall price positioning of the store, it is imperative to follow the price lining strategy. As much as possible, the majority of product groups / line offered to consumers by the store 
must encompass price lining [62]. Based on this concept we have classified the 'price' aspect of the proposed integrated framework as low, mid-low, and mid-price points. Low-Price Points(M2): All the SKUs which are offered by the store belonging to a particular product group bearing an average MRP (maximum retail price / objective price / original price) at least 50 percent lesser than the store's overall price positioning for that particular product group. Mid-Low-Price Points (M1): All the SKUs which are offered by the store belonging to a particular product group bearing an average MRP equivalent to store's overall price positioning for that particular product line. Mid-Price Points (M3): All the SKUs which are offered by the store belonging to a particular product line bearing an average MRP at least 50 percent higher than the store's overall price positioning for that particular product group. For example, if the overall price positioning of the store for Men's essential T-Shirt product line is INR 299 then the mid-low-price points SKUs in the line must be priced at INR 149 on an average and mid-price point SKUs to be priced at INR 449 on an average. We have also considered mid-low-price positioning as best suitable for unorganized lifestyle retailers based on findings from this study. 6.3. Promotion (P3): Promotion is one of the most important aspects in establishing an organized lifestyle store image in employees, competitors and consumers mind and discounts / offers have become even more important post emergence of online store format in India as consumer perspective towards discount has changed dramatically [63]. We have classified promotions by discount type, discount method, discount level, scope of discount applicability / inventory coverage (P3A), consumer level (P3B) and store level promotions $(P 3 C)$ in the proposed integrated framework. These classifications are based on numerous empirical and experimental research we have previously carried out and are relevant to Indian retailing context in addition to taking insights of qualitative findings of this study [64 - 67].

6.4. Place (P4): We are not proposing any specifics regarding where the store should be located in the new integrated framework as the qualitative and empirical findings of this study confirm that the existing store locations of unorganized retailers have a strong advantage to the retailing model. Thus, we have recommended (priority wise) changes to be made to the store itself, such as, a) Store Façade $(P 4 A)$; b) In-Store Lighting $(P 4 B)$; c) Visual Merchandising (P4C) and; d) Visuals of Reputed Brands (P4D).

Grouping of each sub elements of "4P's" clubbed with priority matrix mix within and among "4P's" which have been designed as part of the proposed framework plays an important role in deriving the strength of the proposed model [69]. The grouping and prioritization are the key changes cum rationalization being proposed to the existing retailing model / mix. Our proposed framework has deliberately considered the role of each of these components while designing the new proposition and significantly gives importance to 'input' variables and activities which directly have an impact on consumer repeat visit frequency to the store.

6.5. Employees and Consumers: In addition to these basic " $4 \mathrm{P}$ ' $s$ " what is also important in the retailing model / mix is 'People' both internal and external. During our exploratory phase of this research, we have noticed that all the unorganized lifestyle retailers in the study were following few standard practices such as, a) many representatives of the owner family were giving instructions to store employees across all the aspects of store operation; b) every decision irrespective of the magnitude has to be taken by the owner family members; c) absence of a store manager or in charge and, most importantly d) lower sales personnel strength in the store. Based our findings in this study and taking insights from our previous experimental study [68], we have defined people organization to help the unorganized lifestyle retailers to get organized. As far as the target consumer is concerned, while studying the select unorganized lifestyle retailers, it was observed that majority of them do not have 'focussed' consumer target group and even if they have, they are failing to offer products across life-stage needs of their target consumers. They are neither exploiting the product category they are strong at and nor the target consumer target group they are already catering to through their strong product category. To address this typical issue, we have grouped target consumers into C1: Baby (0-1 Year), Infant (1 to 3 Years), Pregnant Women and Nursing Women. C2: Kids (2 to 8 Years); Boys and Girls (8 to 16 Years); C3: Women (Above 18 Years); C4: Men (Above 18 Years); C5: Entire Family. Unorganized lifestyle retailers need to be cognizant of the universally proven fact that consumer's needs significantly change based on their age and always take this phenomenon into consideration while choosing their target consumers in relation to the product category they offer. Unless store owners and store employees adopt this modification, it becomes very difficult to achieve the organized lifestyle retailer image in competitors and consumers mind.

\section{EXECUTING THE RECOMMENDED FRAMEWORK :}

We are cognizant of the fact and it is inevitable that, the magnitude of changes and rationalizations proposed to the existing retailing model shall need significant attitudinal changes across owners, owners family members 
and the store employees. Thus, we have outlined key recommendations on the wholistic execution of the proposed integrated framework to increase the probability of the success of the proposed model. It is inevitable that to achieve the organized lifestyle retailer image, store owner must attempt to incorporate these recommendations together and across. The proposed model shall not be effective and efficient if the store owner attempts to change its existing retailing model in phases or steps or in silos. As mentioned earlier there are more than 5000 Indian lifestyle brands in addition to well-known global lifestyle brands in India. It is very important to have association and affiliation with reputed Global, National and Local brands which plays an important role in establishing an organized lifestyle retailer image in competitors and consumers mind and it is imperative to all the unorganized lifestyle retailers to strive for constantly associating with reputed brands in such a way it creates positive perceptions and long term memories in consumers mind about the store. If direct association with reputed brands is difficult then it is recommended to use modern online B2B distribution stores (Example: Udaan) which is accessible easily without any hassles. Associating with reputed brands also empowers the store owners to use the brand visuals with or without celebrity pictures, promotion collaterals to enhance the overall store look. In addition, owners can engage their store employees to participate in product training and product range shows arranged by reputed brands from time to time. The proposed integrated framework does not demand the owners to additionally invest on capital on any element of the basic retailing mix except the fourth 'P' which is place. Even as far as 'Place' is concerned we have proposed activities which require new capital to be infused but nevertheless it does not demand any large amount of capital.

\section{DISCUSSION AND CONCLUSION :}

Findings and insights of this exhaustive study which attempted to relatively compare organized and unorganized lifestyle retailing models in India across, a) unit economics; b) returns on investment; c) 94 business deployment factors; d) 192 critical effective factors; and, e) qualitative factors have indicated that in spite of general perception which is in favour of organized retailing models the unorganized lifestyle retailing models in India are superior in majority of retailing model aspects evaluated by us in this study. We do agree that organized retailing model looks good / attractive owing to their store location choice, investment on store design, store ambiance created, capability of spreading their store presence across multiple cities of the country and ability to use mass media to advertise about their store brand, nevertheless they are struggling to make their financials look good on a sustainable basis. What was more concerning and glaring observation in this study was, organized lifestyle retailers believe that they understand their consumers much better than unorganized retailers due to the advanced software tools they have deployed in their customer relationship management (CRM) processes in addition to artificial intelligence (AI) programming they apply to understand consumer behaviour and sales forecasting. Whereas, contradictory to this belief we have found that the key input stage of obtaining relevant consumer data is managed by cashiers of the store at the stage of final billing thereby making the majority of this consumer data obtained irrelevant for efficient usage. As the reliability of this key input consumer data itself is in question they spend most of their time in analysing consumer level performance which does not lead them to any relevant conclusions as far as their communication strategy is concerned. Organized lifestyle retailers understanding of knowing a consumer is successfully obtaining mobile number of a person who shops at their stores and nothing beyond that, whereas understanding a consumer for unorganized retailer means having clear understanding about a consumer's psychological, physiological, socio-economical status in addition to their real-time needs. At the beginning of this study, we assumed that organized lifestyle retailing model is superior in comparison with unorganized retailing, whereas, when we dwelled deep into this study, we realized that there are many aspects of retailing in which organized retailers were inferior to unorganized retailers. Notwithstanding the impact of steadily growing organized retailing in India and its impact on consumer perceptions about unorganized retailers in addition to consumers steadily shifting to organized retailing, it is becoming more and more important and inevitable for unorganized lifestyle retailers in India to get themselves organized at the earliest to arrest this consumer and market share shift to organized retailers. In this context we have attempted to design an integrated framework which is, a) simple to understand; b) easy to execute; and most importantly c) demanding minimal additional capital investment. The proposed framework consciously takes into consideration the fact that the owners of small-scale unorganized lifestyle store would not be able to raise huge funds to invest on beautification of their existing store. We are also not recommending Government agencies to come up with policies or programmes to help these unorganized retailers merely due to the sheer number of such retailers present in India. It would be difficult for any Government agencies to execute any such programmes successfully on such a widely spread 
number of unorganized lifestyle retailers in India. Rather we believe that the unorganized lifestyle retailers implement the proposed framework which integrates all the basic "P's" of the retailing mix to gain long-term, sustainable, competitive, and strategical advantage over organized retailers in India in addition to these unorganized lifestyle retailers getting a chance to become part of the successful organized lifestyle retailers community of the country thereby rationally contributing to the new vision of the country which is known as 'Aatmanirbhar Bharat' or 'Self-Reliant India'.

\section{SUGGESTIONS TO UNORGANIZED LIFESTYLE RETAILERS IN INDIA :}

Based on this research outcome, we would like to determinedly suggest unorganized lifestyle retailers in India that, they need to clearly understand the role of every 'P' of Marketing Mix in relation to their existing / potential consumers, catchment, and merchandise assortment they offer. You also need to clearly understand organized lifestyle retailer's key business objectives behind having stores in cities or locations wherein your store has been operational since generations. Few organized lifestyle retailers may be trying to show exponential growth in their revenue to attract more investors; few may be assuming that consumers acquired based on rich store look, ambiance and advertising tactics as their key components of selling proposition are going to be loyal to their stores forever; few may be trying to create different perceptions in consumers mind over their store image, few may be opening many new stores in premium locations with larger size to tag them as experiential, anchor or destination stores assuming that this effort would lead them to create a premium retailer image in consumers, competitors and investors mind; few may be expanding their presence in catchment areas irrespective of their target consumer groups to promote their retail brand to attract new investors, franchisees and licensees; few conglomerates may be trying to show their presence in the lifestyle retailing segment to strengthen their group portfolio; few may be selling premium priced products, categories, brands to position themselves as premium lifestyle retailers. What is very important is the key business goal of your store, your target consumer group, target consumer group's attitude towards you, your family and the store and most importantly your aim to establish a 'my-store' image in employees and consumers mind. You have many retailing practices which make it very difficult for existing organized retailers to copy and execute in their stores. Continue practising them in addition to implementing the proposed integrated framework.

\section{LIMITATIONS OF RESEARCH :}

The main limitation of this research work is the coverage of various stakeholders viz., number of organized and unorganized lifestyle retailers, product categories, consumer groups, employees, price positioning, regions and cities covered in deriving the proposed framework. This might limit the generalizability of research findings to other set of unorganized retailers in India. The second limitation would be the empirical validation is restricted to few organized and unorganized lifestyle retailers selected for the study and hence the generalizability of the findings and suggestions to other organized and unorganized lifestyle retailers in India. The third limitation would be our ability to carry out an experiment, though we were firm in our approach that, the integrated framework has to be tested in the field before we recommend, it was not that easy merely because of the vast scope of the experiment. Unlike other experiments wherein the treatment is limited to few concepts, components or variables this experiment in fact required us to cover practically almost all the elements of the lifestyle retailing mix which do require longer duration for preparations prior to testing, longer duration prior to the beginning of extracting the results and longer period of time for the experimentation itself to ensure findings and insights are derived holistically. At best we were able to derive recommendations based on our research findings of similar experiments and empirical studies and we shall in some time implement the recommended framework with few select unorganized lifestyle retailers and publish the results. However, as the recommended framework is being derived based on this empirical and previous experimental research finding, it provides significant input regarding the ways in which unorganized lifestyle retailers could utilise these recommendations to start their journey towards becoming a 'successful organized lifestyle retailer' in a sustainably profitable manner.

\section{SCOPE FOR FURTHER RESEARCH :}

We strongly recommended that the recommended framework is experimented by researchers and the same is finetuned further if required for organizing as many unorganized lifestyle retailers in India as possible. Based on the key short-term and long-term business objectives and their target consumer group, unorganized lifestyle retailers can implement the recommended framework and finetune the same based on real-time findings 
relevant to them. The basic principles of the proposed framework with modifications can also be implemented for unorganized retailers in India catering to non-lifestyle product categories too.

\section{REFERENCES :}

[1] Schmitt, B. (2012). The consumer psychology of brands. Journal of Consumer Psychology, 22 (1), 7-17. DOI:10.1016/j.jcps.2011.09.005.

[2] http://www.technopak.com/Files/fashion-retail-scenario-in-india.pdf. Retrieved in June 2020.

[3] http://statisticstimes.com/demographics/population-of-india.php. Retrieved in June 2020.

[4] https://www.mckinsey.com/industries/retail/our-insights/the-state-of-fashion-2019-a-year-of-awakening. Retrieved in June 2020.

[5] https://www.amazon.in/b/?ie=UTF8\&node $=6648217031 \&$ ref $=$ topnav storetab top ap mega.

Retrieved in June 2020.

[6] https://www.mckinsey.com/featured-insights/urbanization/urban-awakening-in-india. Retrieved in June 2020.

[7] Lindquist, J.D. (1974). Meaning of Image: A Survey of Empirical and Hypothetical Evidence. Journal of Retailing, 50(4), 29-38.

[8] Hirschman, E.C., Greenberg, B., \& Robertson, D. (1978). The intermarket reliability of retail image research: an empirical examination. Journal of Retailing, 54(1), 3-12.

[9] Ghosh, A. (1994). Retail Management. Forth Worth, TX: The Dryden Press.

[10] Omar, O. (1999). Retail Marketing. London: Pitman Publishing House.

[11] Mazursky, D. \& Jacoby, J. (1986). Exploring the development of store images. Journal of Retailing, 62(2), 145-165.

[12] Lassk, F.G. (2000). Investigating Aspects of Customer Satisfaction at the c-store: The c-store Product Mix and Image. Journal of Professional Services Marketing, 21(2), 15-26.

[13] Osman, M.Z. (1993). A Conceptual Model of Retail Image Influences on Loyalty Patronage Behavior. International Review of Retail Distribution and Consumer Research, 2,138-148.

[14] Newman, A. J \& Cullen, P. (2002). Retailing; Environment and Operations. London: Thomson Learning.

[15] Newman, A. J. (2003). Some Manipulable Elements of the Service Setting and Their Impact on Company Image and Reputation. International Journal of New Product Development and Innovation Management, 4(3), 287-304.

[16] Lilien, G. L., Kotler, P., \& Moorthy, K. S. (1995). Marketing Models. Prentice Hall.

[17] Sinha, P. K \& Banerjee, A (2004). Store Choice behaviour in an evolving market. International Journal of Retail \& Distribution Management, 32(10), 482-94.

[18] Rosenbloom, B. (1983. Store image development and the question of congruency, in Darden, W.R., Lusch, R. F. (Eds). Patronage Behavior and Retail Management. Elsevier Science Publishing Co., Dordrecht, pp. 141-149.

[19] Amirani, S \& Gates, R (1993). An attribute-anchored conjoint approach to measuring store image, International Journal of Retail and Distribution Management, 21(5), 30-39.

[20] Backer, J. Levy, M. \& Grewal, D. (1992). An Experimental Approach to Making Retail Store Environmental Decisions. Journal of Retailing, 68(2), 445-460.

[21] Day, G. S., \& R, Wensley. (1988). Assessing Advantage: A Framework for Diagnosing Competitive Superiority. Journal of Marketing, 52(2), 1-20.

[22] Ellis, B \& Kelly, S.W. (1992). Competitive Advantage in Retailing. International Review of Retail, 
Distribution and Consumer Research, vol. 2(4), pp. 381-96.

[23] Mendes, R., \& Themindo, C.J. (2004). Retail locations as a competitive strategy. Pearson education, New Delhi.

[24] Reynolds, Jonathan \& Howard, Elizabeth \& Cuthbertson, Christine \& Hristov, Latchezar. (2007). Perspectives on retail format innovation: Relating theory and practice. International Journal of Retail \& Distribution Management.35. 647-660. DOI: 10.1108/09590550710758630.

[25] Krishen. S. A., Bui, M., \& Peter, C. P. (2010). Retail kiosks: how regret and variety influence consumption. International Journal of Retail \& Distribution Management, 38(3), 173-189.

[26] Levy, M., Weitz, B.A., \& Beitelspacher, L.S. (2012). Retailing Management. (8th Edition). McGraw Hill, Irwin.

[27] Ganesha, H. R., Aithal, P. S. \& Kirubadevi P. (2020). Ideal Store Locations for Indian Retailers - An Empirical Study. International Journal of Management, Technology, and Social Sciences (IJMTS), 5(1), 215226.

[28] Ganesha, H. R., Aithal, P. S. \& Kirubadevi P. (2020). Consumer Affordability in Tier-1, Tier-2 and Tier3 Cities of India - An Empirical Study. International Journal of Applied Engineering and Management Letters (IJAEML), 4(1), 156-171.

[29] Ganesha,H. R., \& Aithal, P. S. (2020). Establishing True Lifestyle Brand in India: An Integrated Marketing Mix Framework. International Journal of Management, Technology, and Social Sciences (IJMTS), 5(1), 261-284.

[30] Biel, A. (1993). Converting image into equity. In Brand Equity and Advertising. Aaker, D. and Biel, A. (eds). Lawrence Erlbaum Associates, Hillsdale, NJ, pp.67-82.

[31] Michel Laroche \& Robert Sadokierski (1994). Role of confidence in a multi-brand model of intentions for a high-involvement service. Journal of Business Research, 29(1), 1-12.

[32] Keller, K. L. (1993). Conceptualizing, measuring, and managing customer-based brand equity. Journal of Marketing, 57, 1-22.

[33] Badenhausen, K. (1996, July 8). Blind faith. Financial World, pp. 50-55.

[34] Aaker, D. A. (1991). Managing brand equity. New York: Free Press.

[35] Starčević, S. (2013). Istraživanjekonceptaličnostibrenda u marketingu. Marketing,44(2), 149-172.

[36] Fournier, S. (1998). Consumers and their brands: Developing relationship theory in consumer research. Journal of Consumer Research, 24(4), 343-373.

[37] Reardon, Thomas A. (2005). Retail companies as integrators of value-chains in developing countries. Report commissioned by Federal Ministry for Economic Cooperation and Development, Germany. Eschborn: Trade Matters series by GTZ Trade Programme.

[38] Reardon, T, and Ashok Gulati. (2008). The rise of supermarkets and their development implications International experience relevant for India. International Food Policy Research Institute (IFPRI), discussion paper 00752, 1-49.

[39] Sim, Loo Lee. (1999). Restructuring the small-scale retail sector in Singapore. International Journal of Retail \& Distribution Management, 27 (2), 83-91.

[40] Coe, Neil M. \& Neil Wrigley. (2007). Host economy impacts of transnational retail: The research agenda. Journal of Economic Geography, 7(4), 341-371.

[41] Vishwanathan, Madhu, Jose Antonio Rosa, \& Julie A. Roth. (2010). Exchanges in Marketing Systems: The Case of Subsistence Consumer-Merchants in Chennai, India. Journal of Marketing, 74 (5), 1-17.

[42] Martinez, Alonso, \& Ronald Haddock. (2007). The Flatbed Factory. Strategy + Business, 46, 66-79.

[43] Khare, A. (2013). Retail service quality in small retail sector: the Indian experience. Facilities, 31(5/6), 
208-222.

[44] Andrea, D. Lopez-Aleman, G.B. \& Stengel, A. (2006). Why small retailers endure in Latin America. International Journal of Retail \& Distribution Management, 34(9), 661-673.

[45] Landry, D., Todd J., \& John B. (2005). Retailer Community Embeddedness and Consumer Patronage. Journal of Retailing and Consumer Services, 12(1), 65-72.

[46] Sangvikar, B. \&Katole, H. (2012). A study of consumer purchase behaviour in organized retail outlets. Journal of Business and Retail Management Research, 7(1). 39-47.

[47] Clow, E. \& Cole, H. (2005). Small Retailers road to success. Services Marketing Quarterly, 26(2), 6981.

[48] Swamy, Shekar. (2011). The Pitfalls of FDI in Multi - Brand Retailing in India. Briefing Paper \#3, Madhyam, Delhi.

[49] Kalhan, Anuradha., \& Martin Franz. (2009). Regulation of Retail: Comparative Experience. Economic and Political Weekly, 44 (32), 56-64.

[50] Abivandana, Jain. (2011). Asia Investment Banking Research Report. India Retail Food, NORTHBRIDGE CAPITAL.

[51] Barry, Berman \& Joel, Evans. R. (2007). Retail Management a Strategic Approach. $10^{\text {th }}$ Edition. Pearson Education Inc., Dorling Kindersley Publishing Inc.

[52] Michael, L., \& Barton, W. (2008). Retailing Management. McGraw Hill. Pearson Education Inc., Dorling Kindersley Publishing Inc.

[53] Kamboj, D. (2018). A Study of Relationship between Open Innovation \& Business Model Innovation with Firm Performance. International Journal on Arts, Management and Humanities, 7(1), 71-78.

[54] Aithal P. S, Shailashree V. T., \& Suresh Kumar P. M., (2015). A New ABCD Technique to Analyze Business Models \& Concepts. International Journal of Management, IT and Engineering, 5(4), 409 - 423.

[55] Aithal, P. S. (2016). Study on ABCD Analysis Technique for Business Models, business strategies, Operating Concepts \& Business Systems. International Journal in Management and Social Science, 4(1), 98 $-115$.

[56] McCarthy, E. J. (1960). Basic Marketing: A Managerial Approach. Homewood (Illinois): Richard D. Irwin.

[57] Ganesha, H. R., Aithal, P. S. \& Kirubadevi, P. (2020). Experimental Investigation of Cannibalisation by Introducing a Global Brand Abreast Existing Indian Store Brand. International Journal of Applied Engineering and Management Letters (IJAEML), 4(1), 10-19.

[58] Ganesha, H. R., Aithal, P. S. \& Kirubadevi, P. (2020). Input and Output Driven Sales Personnel Performance Measures: Insights from an Experiment. International Journal of Case Studies in Business, IT, and Education (IJCSBE), 4(1), 23-37.

[59] Ganesha, H. R., Aithal, P. S. \& Kirubadevi, P. (2020). Need-Based Sales Pitch: Insights from an Experiment. International Journal of Case Studies in Business, IT, and Education (IJCSBE), 4(1), 79-87.

[60] Ganesha, H. R., Aithal, P. S. \& Kirubadevi, P. (2020). Integrated Inventory Management Control Framework. International Journal of Management, Technology, and Social Sciences (IJMTS), 5(1), 147-157.

[61] Ganesha, H. R., Aithal, P. S. \& Kirubadevi, P. (2020). Optimal Category Mix in Multi-Category Retailing - Insights from an Experiment. International Journal of Case Studies in Business, IT, and Education (IJCSBE), 4(1), 112-126.

[62] Levy, M., Weitz, B. A., \& Beitelspacher, L. S., (2012). Retailing Management. (8 ${ }^{\text {th }}$ Edition), McGraw Hill, Irwin.

[63] Ganesha, H. R., Aithal, P. S. \& Kirubadevi, P. (2020). Changes in Consumer Perspective towards 
Discount at Brick-and-Mortar Stores owing to Emergence of Online Store Format in India. International Journal of Management, Technology, and Social Sciences (IJMTS), 5(1), 43-83.

[64] Ganesha, H. R., Aithal, P. S. \& Kirubadevi, P. (2020). Short-Term Discounting Frameworks: Insights from Multiple Experiments. International Journal of Case Studies in Business, IT, and Education (IJCSBE), $4(1), 8-22$.

[65] Ganesha, H. R., Aithal, P. S. \& Kirubadevi, P. (2020). Long-Term Discounting Frameworks: Insights from Multiple Experiments. International Journal of Management, Technology, and Social Sciences (IJMTS), $5(1), 84-100$.

[66] Ganesha, H. R., Aithal, P. S. \& Kirubadevi, P. (2020). Decentralized Discounting Framework: Insights from an Experiment. International Journal of Applied Engineering and Management Letters (IJAEML), 4(1), $20-40$.

[67] Ganesha, H. R., Aithal, P. S. \& Kirubadevi, P.(2020). Integrated Discounting Framework for Indian Brick-and-Mortar Retailers. International Journal of Management, Technology, and Social Sciences (IJMTS), 5(1), 110-123.

[68] Ganesha, H. R., Aithal, P. S. \& Kirubadevi, P.(2020). Integrated Discounting Framework for Indian Brick-and-Mortar Retailers. International Journal of Management, Technology, and Social Sciences (IJMTS), 5(1), 110-123.

[69] Ganesha, H. R., Aithal, P. S. \& Kirubadevi, P.(2020). Integrated Marketing Mix Framework for Baby Care Retailing in India. International Journal of Applied Engineering and Management Letters (IJAEML), 4(1), 191-218. 